\title{
NOTE:
}

\section{Antibacterial and Antioxidant Activities of Polyeugenol with High Molecular Weight}

\author{
Erwin Abdul Rahim*, Nur Istiqomah, Gilang Almilda, Ahmad Ridhay, Ni Ketut Sumarni, and Indriani \\ Department of Chemistry, Tadulako University, Jl. Sukarno-Hatta Km 9, Palu 94148, Central Sulawesi, Indonesia
}

\author{
* Corresponding author: \\ email:erwin_abdulrahim@yahoo.com \\ Received: April 1, 2019 \\ Accepted: September 5, 2019 \\ DOI: $10.22146 / \mathrm{ijc} .44659$
}

\begin{abstract}
This study was aimed to prepare polyeugenol with high molecular weight and to evaluate its antibacterial and antioxidant activities. First, polyeugenol was synthesized from eugenol in the presence of $\mathrm{H}_{2} \mathrm{SO}_{4}-\mathrm{CH}_{3} \mathrm{COOH}$ (4:1) as catalyst. The synthesized polyeugenol was weighed by using viscometer, revealing its high molecular weight of $(7.76-21.9) \times 10^{5} \mathrm{~g} / \mathrm{mol}$. Furthermore, the antibacterial activity of the polyeugenol was conducted against Staphylococcus aureus and Escherichia coli bacteria. It was conducted by applying well diffusion method at 1, 2, 3, 4 and 5\% concentrations to observe inhibition zones, in which the tests showed that the antibacterial activity of the polyeugenol against $\mathrm{S}$. aureus were 17.42, 17.76, 18.79, 21.42 and $22.55 \mathrm{~mm}$, while those against $\mathrm{E}$. coli were 15.87, 17.23, 17.56, 18.24 and $19.21 \mathrm{~mm}$, respectively. In short, these results indicated a strong antibacterial activity. Then, tests on antioxidant activity against free radical DPPH (2,2-diphenyl-1-pycrylhydrazyl) gave the $I C_{50}$ value of $80.47 \mu \mathrm{g} / \mathrm{mL}$, indicating a strong antioxidant activity. Therefore, the polymer synthesized in this work has a high potential to be applied in various biomedical applications.
\end{abstract}

Keywords: polyeugenol; high molecular weight; antibacterial activity; antioxidant activity

\section{- INTRODUCTION}

Eugenol is the major component in clove oil (Syzygium aromaticum), reaching 70-96\% of oil content. Eugenol $\left(\mathrm{C}_{10} \mathrm{H}_{12} \mathrm{O}_{2}\right)$ contains several functional groups, including allyl $\left(-\mathrm{CH}_{2}-\mathrm{CH}=\mathrm{CH}_{2}\right)$, phenol $(-\mathrm{OH})$ and methoxy $\left(-\mathrm{OCH}_{3}\right)$. These functional groups allow eugenol to act as the base material for the synthesis of more valuable compounds, including polyacetylene containing eugenol moiety [1-4], epoxy resin with extremely high biomass content from eugenol [5], bio-renewable thermosetting copolymer based on eugenol [6], renewable eugenol-based polymeric oil-absorbent microspheres [7], and UV-cured thiol-ene eugenol/ZnO composite [8].

In fact, eugenol compound and its various derivative compounds have been recognized to have strategic roles in various industries such as pharmaceutical, cosmetics, food and beverage, cigarette, vegetable, fishery, mining, active packaging and other chemical industries [9]. Practically, eugenol can be further processed into a variety of more useful products, including polyeugenol. Besides isoeugenol, polyeugenol is a result of further derivatization of eugenol. In the literature, various researches have successfully developed techniques and methods to create polymers that suit certain purposes such as having antibacterial and antioxidant properties. Those advances have made the polymer industry to undergo rapid developments [10].

In a recent study, Prasetya et al. [11] had synthesized polyeugenol with low molecular weight. The polymer, however, showed low antibacterial activity towards Staphylococcus aureus and Escherichia coli. Therefore, the purpose of this study was to synthesize polyeugenol with high molecular weight and to improve the antibacterial and antioxidant activities compared to eugenol. Practically, this work would result in creating a polymer from eugenol with considerably good antibacterial and antioxidant properties.

\section{- EXPERIMENTAL SECTION}

\section{Materials}

This study used various materials for the experiments, including eugenol (99.99\% purity; obtained 
from Happy Green Co.), $\mathrm{H}_{2} \mathrm{SO}_{4}, \mathrm{CH}_{3} \mathrm{COOH}$ glacial, silica gel, distilled water, ethanol (98\%), Whatman filter paper no. 1, 1,1-diphenyl-2-pycrylhydrazyl (DPPH), S. aureus and E. Coli bacteria (Obtained from Health Laboratory, Palu, Central Sulawesi), dimethyl sulfoxide (DMSO), $n$-hexane, petroleum ether (technical grade), nutrient agar (NA), Chloramphenicol, aluminum foils and plastic wraps.

\section{Instrumentation}

In terms of equipment and instruments, this research used measuring cups $(250 \mathrm{~mL}, 50 \mathrm{~mL}, 25 \mathrm{~mL})$, magnetic stirrer/mixer, spray bottle, dropper drip, pipettes $(5 \mathrm{~mL}$, $1 \mathrm{~mL}$ ), petri dishes, aluminum foil, hot plate, analytical balance, dry cloth, spatulas, test tubes, micropipettes, tube racks, instruments for UV-VIS analysis, autoclave, incubator, rotary vacuum evaporator, Ostwald viscometer (U-tube), stopwatch, skates, Bunsen burner, needles and other glass-based tools commonly used in the laboratory.

\section{Procedure}

\section{Polymerization of eugenol [12]}

As much as $10 \mathrm{~g}$ of eugenol was placed into a $250 \mathrm{~mL}$ measuring cup. Next, $2.5 \mathrm{~mL}$ of catalyst $\left(\mathrm{H}_{2} \mathrm{SO}_{4}\right.$ $\mathrm{CH}_{3} \mathrm{COOH} ; 4$ mol $\mathrm{H}_{2} \mathrm{SO}_{4}: 1 \mathrm{~mol} \mathrm{CH}_{3} \mathrm{COOH}$ ratio) was gradually added into the cup while being continuously mixed (room temperature, $5 \mathrm{~min}$ ) by using a magnetic stirrer. Polymer formation was indicated by the release of concentrated white smoke and the appearance of formed polymer. To stop the polymerization, methanol $(1 \mathrm{~mL})$ was added to the cup. After that, the polymer was settled at room temperature for $24 \mathrm{~h}$ and was then identified. Next, as much as $2 \mathrm{~g}$ of polyeugenol was decentered in a $250 \mathrm{~mL}$ Erlenmeyer. An amount of $40 \mathrm{~mL}$ of diethyl ether was later added to the bottle. The bottle was sealed with a plug to then be shaken until the polyeugenol was completely dissolved. After that, the dissolved polyeugenol was divided into two $250 \mathrm{~mL}$ cups. For each cup, a toe of $100 \mathrm{~mL}$ was added, then each cup was shaken and kept for one night. In the following day, the bottom and upper layers was segregated, in which the upper part had its restored form. Then, they were washed 3 times. Practically, the top layer would be soluble in ether but not soluble in water. To ensure no water residual in the polyeugenol, $1 \mathrm{~g}$ of anhydrous $\mathrm{Na}_{2} \mathrm{SO}_{4}$ was added and filtered. Then, the filtrate was placed in a petri dish and kept for $48 \mathrm{~h}$ at room temperature.

\section{Determination of molecular weight of polyeugenol}

Polyeugenol was dissolved in ethanol to a concentration of $0.02 \mathrm{~g} / \mathrm{mL}$ in a $50 \mathrm{~mL}$ flask. After that, the polymer was divided into five, and each of them was diluted with ethanol to the following concentrations: $0.01500 ; 0.01000 ; 0.00500 ; 0.00250$ and $0.00125 \mathrm{~g} / \mathrm{mL}$. Next, the percentage of pure ethanol solvent was measured in Ostwald viscometer to discover the concentration of the polymer solution, producing $t_{0}, t_{1}$, $t_{2}, t_{3}, t_{4}, t_{5}$, and $t_{6}$. Using the Poisseuille equation ( $\eta \mathrm{sp} / \mathrm{C}$ ) versus $\mathrm{C}$ was obtained. The curve was then extrapolated to zero concentration $(\mathrm{C}=0)$ to obtain $[\eta]$. Using the Mark-Houwink equation $\left(\eta=\mathrm{K} \cdot \mathrm{M}^{\mathrm{a}}\right)$, the molecular weight of the polymer was calculated by taking the corresponding $\mathrm{K}$ and a into account.

\section{Antibacterial activity assay of polyeugenol using well diffusion method}

This study applied a well diffusion method to test the inhibition zone of bacteria. First, $25 \mathrm{~mL}$ of nutrient agar (NA) medium was mixed with $25 \mu \mathrm{L}$ suspension of test bacteria (S. aureus and E. coli). Next, it was homogenized and poured in sterilized petri dishes and left to get solidified. After that, $\pm 9 \mathrm{~mm}$ holes/wells were made by using a piercing device. Three holes were made to the first cup (i.e. first hole for polyeugenol with $1 \%$ concentration, second hole for polyeugenol $2 \%$, third hole for polyeugenol 3\%). Meanwhile, two holes/wells were made to the second plate (i.e. first hole for polyeugenol $4 \%$, second hole for polyeugenol $5 \%$ ). Then, two holes/wells were made to the third plate (i.e. first hole for negative control, second hole for positive control of chloramphenicol $250 \mu \mathrm{L} / 50 \mu \mathrm{L}$ ). The treatment was repeated three times, incubated for $24 \mathrm{~h}$ at $37^{\circ} \mathrm{C}$, and then observed to measure the diameter of the drag zone by using a sliding range. Three replicates were tested for each experiment.

\section{Antioxidant activity assay of polyeugenol using DPPH method}

$25 \mathrm{mg}$ of polyeugenol with high molecular weight was weighed and placed into a $25 \mathrm{~mL}$ measuring flask. 
Next, ethanol was gradually added to reach 1000 ppm concentration to be used as a stock solution. Later, $10 \mathrm{~mL}$ of the stock solution was taken by using a volumetric flask, then filled into a $100 \mathrm{~mL}$ measuring flask. Ethanol was then added to the flask to obtain a solution with $100 \mathrm{ppm}$ concentration. To investigate the antioxidant activity, $0.2 \mathrm{~mL}$ of each concentration was piped by using a micropipette as sample solutions and placed into a vial. Next, $3.8 \mathrm{~mL}$ of DPPH solution $50 \mu \mathrm{M}$ was added into the vial. After that, the mixture was homogenized and kept in a dark room for $30 \mathrm{~min}$. Then, the uptake was measured by a UV-VIS spectrophotometer at a $517 \mathrm{~nm}$ wavelength. Absorption at DPPH $50 \mu \mathrm{M}$ was measured as a control. The antioxidant activity was expressed in terms of the percentage of inhibition and calculated by using Eq. (1).

$\mathrm{I}(\%)=\frac{\text { Control Absorbance }- \text { Sample Absorbance }}{\text { Control Absorbance }} \times 100 \%$

where: Control Absorbance $=$ absorbance of DPPH $50 \mu \mathrm{M}$; Sample Absorbance $=$ Absorbance of test sample

The $\mathrm{IC}_{50}$ value of each concentration was calculated by using the linear regression equation formula obtained from the relationship curve between the percentages of inhibition to the sample concentration.

\section{- RESULTS AND DISCUSSION}

\section{Synthesis of Polyeugenol}

In general, cationic polymerization is limited to monomers with electron-donating substituents where double bond polarization makes them sensitive to electrophilic attacks by carbonyl [13]. According to Cowd [9], only monomers have electron-donating groups that can undergo cationic polymerization. The use of acetic acid as co-catalyst will be corresponding to high molecular weight polymer. Cationic olefins monomers polymerization occurs with olefins $\mathrm{CH}_{2}=\mathrm{CHR}$ containing electron-donating substituents, $\mathrm{R}_{2} \mathrm{C}=\mathrm{Z}$ compounds with hetero $\mathrm{Z}$ groups or hetero atoms, and cyclic molecules with hetero atoms as a structural part of the ring [13].

Synthesis of polyeugenol was conducted in this study through the cationic polymerization reaction with $\mathrm{H}_{2} \mathrm{SO}_{4}-\mathrm{CH}_{3} \mathrm{COOH}$ as the catalyst. During the polymerization process, the synthesis was observed by thickened white smoke, in which the resulting polymer was attached to the beaker and the color became purplish black.

The purification step resulted in the formation of two layers. The bottom layer was water and the catalyst, while the top layer was the produced polyeugenol. Diethyl ether was used as a polyeugenol solvent because it was nonpolar and would not get mixed with water during the washing process. Fig. 1 shows the IR spectra of eugenol and polyeugenol. Results of the FTIR spectrum of polyeugenol showed a wide absorption at wavenumber $3448 \mathrm{~cm}^{-1}$, indicating vibration of $-\mathrm{OH}$ groups. In the FTIR spectrum of eugenol, the -OH group was located at wavenumber $3518 \mathrm{~cm}^{-1}$. Next, peaks at $2870-2931 \mathrm{~cm}^{-1}$ showed the vibration of $\mathrm{Csp}^{3}-\mathrm{H}$ stretches. Meanwhile, the presence of a conjugated aromatic compound was shown by absorption bands at 1604 and $1512 \mathrm{~cm}^{-1}$. Besides that, peaks at wavenumber $2839-2908 \mathrm{~cm}^{-1}$ within the IR spectrum of eugenol showed a $\mathrm{Csp}^{3}-\mathrm{H}$ vibration, while the presence of an aromatic compound was indicated by absorption bands at 1604 and $1512 \mathrm{~cm}^{-1}$. The $\mathrm{C}=\mathrm{C}$ aromatic spectrum was observed at wavenumber of $1500-1600 \mathrm{~cm}^{-1}$, while the stretching vibration of $\mathrm{Csp}^{3}$ $\mathrm{H}$ was indicated by the absorption at $3000-2840 \mathrm{~cm}^{-1}$. The presence of absorption bands within the IR spectrum of eugenol showed that the absorption at $1635 \mathrm{~cm}^{-1}$ was a characteristic of absorption band for the range $\mathrm{C}=\mathrm{C}$,

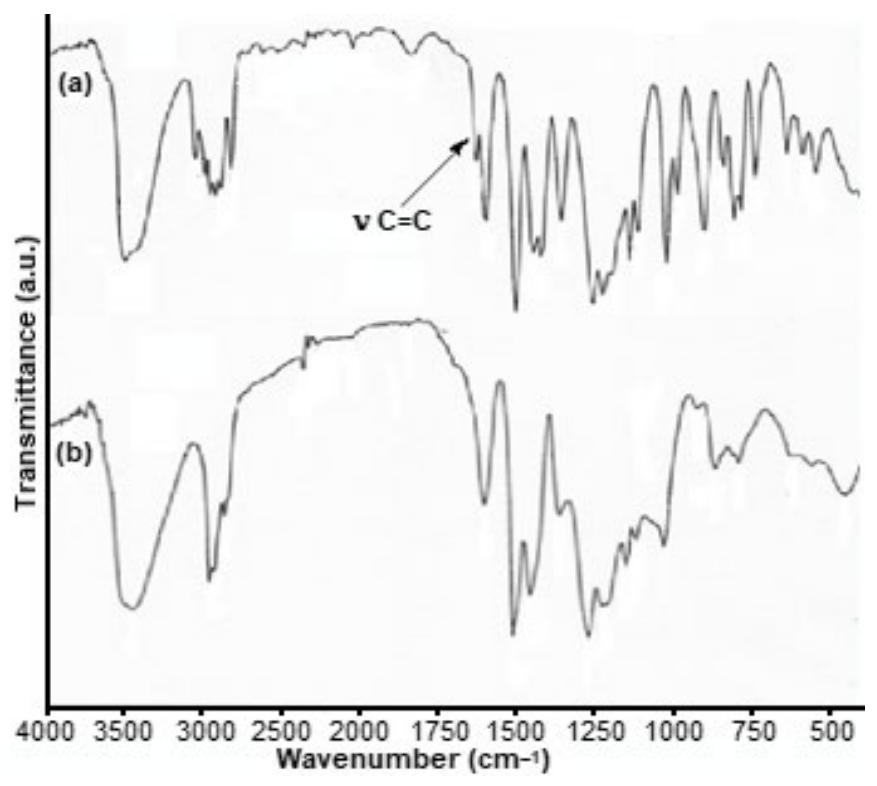

Fig 1. IR spectra of (a) eugenol and (b) polyeugenol 
which was strengthened by absorption bands out of the field at $900-648 \mathrm{~cm}^{-1}$. Then, peaks at 995 and $910 \mathrm{~cm}^{-1}$ showed unsaturated groups in the form of vinyl groups $\left(-\mathrm{CH}=\mathrm{CH}_{2}-\right)$. Based on the explanation above, the compound contained ether (C-O-C-); - OH; methyl (- $\left.\mathrm{CH}_{3}\right)$, methylene $\left(-\mathrm{CH}_{2}-\right)$ and vinyl groups.

Furthermore, peaks at wavenumber 1637 and $995 \mathrm{~cm}^{-1}$, which was typical for the absorption for the vinyl group, appeared within the IR spectrum of eugenol, while it did not appear at the spectrum of polyeugenol. Hence, it indicated the formation of polyeugenol. Apparently, the purification, the IR spectrums and the ratio between eugenol and $\mathrm{H}_{2} \mathrm{SO}_{4}$ catalyst (4:1) are the same as the results of a previous work by Ngadiwiyana [14]. Fig. 2 illustrates the polymerization of eugenol with $\mathrm{H}_{2} \mathrm{SO}_{4}-\mathrm{CH}_{3} \mathrm{COOH}$ catalyst. The polyeugenol was obtained in $88.28 \%$ yield together with an unknown compound (11.27\% yield) which is soluble in water.

\section{Determination of Molecular Weight of Polyeugenol}

Based on the calculation on the molecular weight of polyeugenol, the resulting polymer was obtained as a solid form with $(7.76-21.9) \times 10^{5} \mathrm{~g} / \mathrm{mol}(\mathrm{n}=13.134$ repeating unit) molecular weight, indicating that this study successfully produced polyeugenol with high molecular weight. The molecular weight of polyeugenol obtained in this study is higher than that obtained by Ngadiwiyana [14] which was $7.800 \mathrm{~g} / \mathrm{mol}$. In addition, the molecular weight after purification was, in fact, greater than that of Junaidi's work [15], in which the weight of polyeugenol produced during an ether fraction was $5.140 \mathrm{~g} / \mathrm{mol}$.

\section{Antibacterial Activity Test of Polyeugenol}

This test applied dimethyl sulfoxide (DMSO) as a solvent with 1, 2, 3, 4 and $5 \%$ concentrations. DMSO was

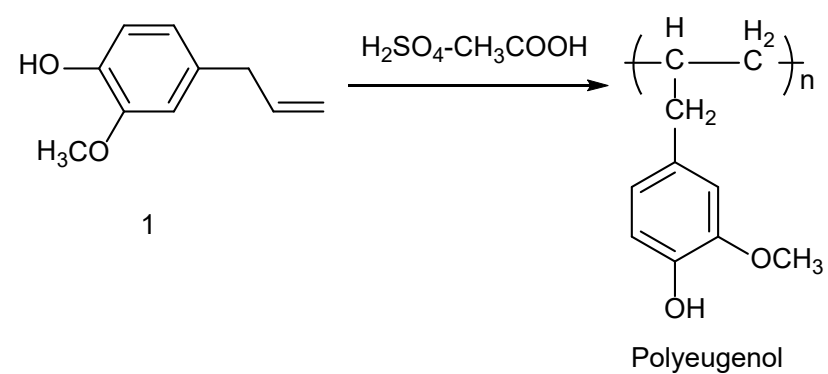

Fig 2. Synthesis of polyeugenol employed since it could dissolve almost all polar and non-polar compounds. Besides, DMSO would prevent the inhibition of bacterial growth, hence it would not be interfering with the result of observations on antibacterial activity. Looking at the test results (Table 1), the diameters of inhibition zones for the $S$. aureus and E. coli test bacteria increased in parallel with the increase in concentration. The results showed that the inhibition zones of polyeugenol tested against $S$. aureus were relatively higher than those tested against E. coli. E. coli is recognized as Gram-negative bacteria, while $S$. aureus is known as Gram-positive bacteria. Thus, polyeugenol with high molecular weight showed a stronger inhibitory power against Gram-positive bacteria compared to Gram-negative bacteria.

In general, the cationic bactericidal mechanism occurs due to the interactions and destructions of cell membrane structures. In Gram-positive bacteria, the cell membrane is covered by a cell wall, which is composed of 30-40 peptidoglycan layers [16]. Furthermore, there are the bound location of the positive charge of polyeugenol hydroxyl group, causing distortion and breakdown of the cell wall due to osmotic shock and cytoplasmic exudation of the content. In contrast, Gram-negative bacteria have an outer membrane layer (containing lipopolysaccharide and protein), one or two peptidoglycan (cell wall) and cell membranes (consisting of two layers of fat), transmembrane proteins and an inner membrane layer. Practically, the O-chain negative charge of lipopolysaccharide is bound to the positive charge of the polyeugenol's hydroxyl group, hence blocking the flow of nutrients in bacteria that ultimately leads to cell death due to the strong association between the $\mathrm{O}$-chain and the outer membrane. In addition, the eugenol-free hydroxyl group can bind negative charge on the surface of bacterial cells, which will eventually perform antibacterial effects [17].

Table 1 and Fig. 3 shows antibacterial activities of polyeugenol at every concentration level and repetition. The inhibition zone appears to be larger in parallel to the increase of concentrations. The differences in inhibitory power of an antibacterial compound against Grampositive and Gram-negative bacteria were particularly 
Table 1. Inhibition zones of polyeugenol

\begin{tabular}{|c|c|c|c|c|c|c|c|c|c|}
\hline \multirow{3}{*}{ Bacterial } & \multirow{3}{*}{ Repeated } & \multicolumn{7}{|c|}{ Inhibition Zones (mm) } & \multirow{3}{*}{ Eugenol [17] } \\
\hline & & \multicolumn{5}{|c|}{ Concentration (\%) } & \multicolumn{2}{|c|}{ Control } & \\
\hline & & 1 & 2 & 3 & 4 & 5 & $(+)$ & $(-)$ & \\
\hline S. Aureus & Average & 17.42 & 17.76 & 18.79 & 21.42 & 22.55 & 37.14 & - & 7.75 \\
\hline E. Coli & Average & 15.87 & 17.23 & 17.56 & 18.24 & 19.21 & 44.40 & - & 9.25 \\
\hline
\end{tabular}

caused by the structures of their cell walls. The cell wall of Gram-positive bacteria consists of several peptidoglycan layers, forming a thick and rigid structure and contains teichoic acid. Meanwhile, the cell wall of Gram-negative bacteria consists of one or more thin peptidoglycan layers, hence the cell wall is more susceptible to physical shocks, including antibiotics or other antibacterial agents. The difference in cell wall structure has caused both bacteria to respond to Gram staining [18].

The previous study conducted by Prasetya et al. [11] had prepared polyeugenol by applying cationic polymerization method with $\mathrm{BF}_{3}$ catalyst and conducted the antibacterial test against $S$. aureus and E. coli bacteria. The work demonstrated that the activities against $S$. aureus and E. coli were lower than our study. Apparently, the results of this study (Table 1) differ from previous results, particularly on the non-existence of antibacterial activity in Gram-negative bacteria (E. coli). It was probably due to the differences in polyeugenol molecular weight $(\mathrm{Mw})$ and the catalyst being used. The prior study showed that the antibacterial activity of eugenol could inhibit lower growth of pathogenic bacterial E. coli, and $S$. aureus. Yalpani et al. [18] had also reported that the degree of polymerization was directly proportional to increased inhibitory activity. The spacer length or alkyl chain length refers to the length of the carbon chain that composes the polymer backbone. The chain length has been investigated to see if it affects the antimicrobial activity of the polymer. The results have generally shown that the longer alkyl chains have resulted in higher activity.

Some of the major chemical compounds that have antibacterial properties include phenols as well as phenolic compounds, alcohols, halogens, heavy metals, aldehydes and detergents [19]. In particular, the 3-(3,4dimethoxyphenyl)-1-propanol unit in polyeugenol is alcohol primarily produced from the synthesis, making the

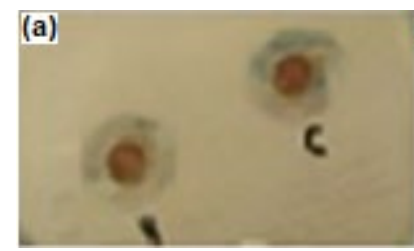

(b)

Fig 3. Inhibition zones of polyeugenol against (a) $S$. aureus and (b) E. coli

antibacterial mechanism to be similar to other alcohols. Looking at the study, polyeugenol with high molecular weight would have higher antibacterial activity than its previous forms as eugenol compound.

According to Davis and Stout [20], the antibacterial activity could be considered as strong when it produces inhibition area between 10-20 mm. Meanwhile, inhibition zone with 5-10 $\mathrm{mm}$ diameter was considered to have medium antibacterial activity, and less than $5 \mathrm{~mm}$ diameter was categorized as having a low antibacterial activity. Based on these classifications, the antibacterial inhibition of polyeugenol with high molecular weight against $S$. aureus test bacteria at 1,2 and $3 \%$ concentrations were considered strong, while at 4 and 5\% concentrations were considered very strong. On the other hand, the antibacterial inhibition against $E$. coli test bacteria at 1, 2, 3,4 and $5 \%$ concentrations were considered strong. Thus, the best concentration for inhibiting bacteria was at 5\% concentration. In other words, the higher the presence of polyeugenol in a medium, the higher the number of bacterial cell diffusions.

\section{Antioxidant Activity Test using DPPH Method}

The antioxidant activity of eugenol and polyeugenol compounds were performed by applying DPPH method with vitamin $\mathrm{C}$ as a control. In this study, the $\mathrm{IC}_{50}$ value of eugenol compound was found to be $128.59 \mu \mathrm{g} / \mathrm{mL}$, while that of polyeugenol was $80.47 \mu \mathrm{g} / \mathrm{mL}$. Then, the $\mathrm{IC}_{50}$ value of vitamin C was revealed to be $42.94 \mu \mathrm{g} / \mathrm{mL}$ (Table 2). 
Table 2. Antioxidant activity of polyeugenol using DPPH method

\begin{tabular}{lrrrc}
\hline \multirow{2}{*}{ Compounds } & \multicolumn{3}{c}{$\mathrm{IC}_{50}(\mu \mathrm{g} / \mathrm{mL})$} & $\begin{array}{c}\text { Average of } \mathrm{IC}_{50} \\
(\mu \mathrm{g} / \mathrm{mL})\end{array}$ \\
\cline { 2 - 4 } & \multicolumn{1}{c}{$\mathrm{I}$} & \multicolumn{1}{c}{$\mathrm{II}$} & \multicolumn{1}{c}{$\mathrm{III}$} & 128.59 \\
Eugenol & 135.22 & 125.60 & 125.44 & 80.47 \\
Polyeugenol & 84.13 & 78.01 & 79.83 & 42.94 \\
Vitamin C & 43.72 & 42.25 & 42.81 & \\
\hline
\end{tabular}

In terms of relationships between the concentrations of extract to the percentage of inhibition, in short, the lower the concentration of a sample, the lower the value of inhibition to free radical activity. In other words, inhibition of free radicals would increase if the sample concentration increased. In terms of $\mathrm{IC}_{50}$ values, they appeared to be inversely proportional to the antioxidant capability of a compound. The smaller the value of $\mathrm{IC}_{50}$, the greater the antioxidant ability of a compound. In general, $\mathrm{IC}_{50}$ value is stated as a value indicating the amount of sample concentration that can capture DPPH free radical by $50 \%$. Therefore, this study discovered polyeugenol compound to have a considerably strong antioxidant activity.

In detail, the presence of phenolic compounds in polyeugenol would cause the compound to have good antioxidant activity. This occurs because the phenolic compound is known to have hydroxyl groups $(\mathrm{OH})$. Practically, hydrogen atom of the phenolic group would be donated to a radical compound to get stabilized. Besides, this study had produced polyeugenol with high molecular weight, hence its antioxidant properties would surely be higher than eugenol. Increased antioxidant activity of the synthesized polyeugenol compound, in fact, was due to electronic and steric effects of the phenol ring, resulting in stability of free radical inhibition [19]. Therefore, the polyeugenol synthesized in this research offered great potentials as a source of antioxidants.

\section{- CONCLUSION}

Polyeugenol with high molecular weight was synthesized by using $\mathrm{H}_{2} \mathrm{SO}_{4}-\mathrm{CH}_{3} \mathrm{COOH}$ catalyst and was discovered to have antibacterial properties. Its highest inhibitory power was revealed at a $5 \%$ concentration with very strong inhibition diameter $(22.55 \mathrm{~mm})$ for $S$. aureus and strong inhibition diameter $(19.21 \mathrm{~mm})$ for E. coli bacteria. In terms of antioxidant activity, on the other hand, polyeugenol was discovered to demonstrate its antioxidant activity with a strong $\mathrm{IC}_{50}$ value category $\left(\mathrm{IC}_{50}=80.47 \mu \mathrm{g} / \mathrm{mL}\right)$. Therefore, the polymer can be considered as being highly applicable for various biomedical applications.

\section{- ACKNOWLEDGMENTS}

The authors thanks the Faculty of Mathematics and Natural Sciences, Tadulako University, Indonesia, for their support during this research.

\section{- REFERENCES}

[1] Rahim, E.A., Sanda, F., and Masuda, T., 2004, Synthesis and properties of novel polyacetylene containing eugenol moieties, J. Macromol. Sci. Part A Pure Appl. Chem., 41 (2), 133-141.

[2] Rahim, E.A., Sanda, F., and Masuda, T., 2004, Synthesis and properties of novel eugenol-based polymers, Polym. Bull., 52 (2), 93-100.

[3] Rahim, E.A., 2018, Unique polymerization and new smart material of eugenol-based helical polymers, Int. J. Sci. Res., 7 (11), 990-996.

[4] Rahim, E.A., Sanda, F., and Masuda, T., 2006, Synthesis and properties of optically active amino acid-based polyacetylenes bearing eugenol and fluorene moieties, J. Polym. Sci., Part A: Polym. Chem., 44 (2), 810-819.

[5] Miao, J.T., Yuan, L., Guan, Q., Liang, G., and Gu, A., 2017, Biobased heat resistant epoxy resin with extremely high biomass content from 2,5furandicarboxylic acid and eugenol, ACS Sustainable Chem. Eng., 5 (8), 7003-7011.

[6] Liu, K., Madbouly, S.A., and Kessler, M.R., 2015, Biorenewable thermosetting copolymer based on soybean oil and eugenol, Eur. Polym. J., 69, 16-28.

[7] Deng, J., Yang, B., Chen, C., and Liang, J., 2015, Renewable eugenol-based polymeric oil-absorbent 
microspheres: Preparation and oil absorption ability, ACS Sustainable Chem. Eng., 3, 599-605.

[8] Modjinou, T., Tobias, H.R., Morales, G., Versache, D.L., Langlois, V., Grande, D., and Renard, E., 2016, UV-cured thiol-ene eugenol/ZnO composite materials with antibacterial properties, $R S C A d v ., 6,88135$.

[9] Cowd, M.A., 1982, Polymer Chemistry, John Murray Publishers Ltd, London.

[10] Rojo, L., Barcenilla, J.M., Vázquez, B., Gonzáles, R., and Román, J.S., 2008, Intrinsically antibacterial material based on polymeric derivatives of eugenol for biomedical applications, Biomacromolecules, 9 (9), 2530-2535.

[11] Prasetya, N.B.A., Ngadiwiyana, Ismiyarto, and Sarjono, P.R., 2019, Synthesis and study of antibacterial activity of polyeugenol, IOP Conf. Ser.: Mater. Sci. Eng., 509, 012101.

[12] Sitti, A.H., Erwin, A.R., and Musafira, 2018, Sintesis dan karakteristik polyeugenol dari eugenol menggunakan katalis $\mathrm{H}_{2} \mathrm{SO}_{4}-\mathrm{CH}_{3} \mathrm{COOH}$, Kovalen, 4 (3), 285-296.

[13] Remmp, P., and Merril, E.W., 1991, Polymer Synthesis, Hutting and Wept, New York.

[14] Ngadiwiyana, 2005, Polimerisasi eugenol dengan katalis asam sulfat pekat, JKSA, 8 (2), 43-47.

[15] Djunaidi, M.C., Jumina, J., Siswanta, D., and Ulbricht, M., 2015, Synthesis of Fe ionic-imprinted polyeugenol using polyethylene glycol diglycidilether as cross-linking agent for sorption of $\mathrm{Fe}(\mathrm{III})$, Indones. J. Chem., 15 (3), 305-314.

[16] Kittur, F.S., Kumar, A.B.V., Varadaraj, M.C., and Tharanathan, R.N., 2005, ChitooligosaccharidesPreparation with the aid of pectinase ribozyme from Aspergillus niger and their antibacterial activity, Carbohydr. Res., 340 (6), 1239-1245.

[17] Rastina, Sudarwanto, M., and Wientarsih, I., 2015, Aktivitas antibakteri ekstrak etanol daun kari (Murraya koenigii) terhadap Staphylococcus aureus, Escherichia coli, dan Pseudomonas sp., J. Ked. Hewan, 9 (2), 185-188.

[18] Yalpani, M., Johnson, F., and Robinson, L.E., 1992, "Antimicrobial activity of some chitosan derivatives" in Advances in Chitin and Chitosan, Eds. Brine, C.J., Sandford, P.A., and Zikakis, J.P., Elsevier, London, 543-548.

[19] da Silva, F.F.M., Monte, F.J.Q., de Lemos, T.L.G., do Nascimento, P.G.G., de Medeiros Costa, A.K., and de Paiva, L.M.M., 2018, Eugenol derivatives: Synthesis, characterization, and evaluation of antibacterial and antioxidant activities, Chem. Cent. J., 12, 34 .

[20] Davis, W.W., and Stout, T.R., 1971, Disc plate method of microbiological antibiotic assay, Appl. Microbiol., 22 (4), 659-666. 